\title{
Learning a Foreign Language During a Pandemic: Developing Podcast for Listening Skill of Beginner-Level BIPA Learners
}

\author{
Asih Zunaidah ${ }^{1 *}$, Mufidah Nur Amalia ${ }^{2}$, Candrika Citra Sari ${ }^{1}$, Gamal Kusuma \\ Zamahsari $^{1}$ and Zidan Febrian ${ }^{3}$ \\ ${ }^{1}$ Communication Science Department, Faculty of Economics \& Communication, Bina Nusantara University, \\ Jakarta, Indonesia, 11480 \\ ${ }^{2}$ Computer Science Department, School of Computer Science, Bina Nusantara University, Jakarta, Indonesia, \\ 11480 \\ ${ }^{3}$ Public Relations Department, Faculty of Economics \& Communication, Bina Nusantara University, Jakarta, \\ Indonesia, 11480 \\ *Corresponding Author email: asih.zunaidah@binus.edu
}

\begin{abstract}
In a digital era, the process of learning is no longer limited to space and time. In recent educational technology, Podcast serves as a useful alternative since it can be used for learning of a language digitally and independently. Accordingly, the Indonesian language is currently one of the languages widely studied by international students, known as Indonesian Language for Foreign Speakers (henceforth, it is referred to as BIPA). The dissemination of the Indonesian language to develop, foster, and improve it internationally is stated in the XI Indonesian Language Congress in 2018. This research aimed to develop a listening learning-media for BIPA at beginner-level based on the Ministry of Education and Culture curriculum. This research was conducted to assist BIPA learners in more flexible learning. Amid the Covid-19 pandemic, all learners have to study at home. Therefore, developing Podcast as an independent-learning media is a solution to overcome this problem. It is useful because learners can access the materials anywhere and anytime. The podcast development method adopted and modified Borg \& Gall's R\&D cycle. There were five steps involved in the process: (1) Need analysis, (2) Product Development, (3) Expert Validation, and (4) Product Revision, and (5) Final product prototype. The podcast featured fifteen sub-topics related to the following topics: surrounding environment, daily activities, and important places; the topics were adjusted to the beginner-level of BIPA graduate competency standards from the Ministry of Education and Culture. After going through a series of development cycles, testing, and revision, the BIPA podcast is ready for beginner-level learners.
\end{abstract}

Keywords: Beginner-level, BIPA, Independent learning, Listening skill, Podcast

\section{INTRODUCTION}

Some educators believe that face-to-face courses are the best for language learning, supported by Spodark [1]; he asserted that language learners at entry levels learn best in face-to-face course settings. Nevertheless, without entirely discrediting this notion, an optimal learning experience also requires an ideal number of students in the class, welldeveloped course materials, and the teacher's skill in delivering them, without which any learning goal will not be successful. Educators must be ready for any changes and development in teaching-learning methods, especially when dealing with unprecedented situations.

The year 2020 marks the starting point of massive disruption in education. Before the covid-
19, language learners and educators did not have any problems interacting and running the classes. Traditional and offline learning never had to face perils when the virus was declared a global threat at the beginning of 2020. Language instructors sought ways to deal with the situation as students could no longer have face-to-face classes. The online method has been one of the options for solving the problem. After the pandemic impacted various learning systems, educators have tried to cope with the challenges. Setting about online learning is no longer a matter of preference, as everyone must conform to health protocols to stay safe. The end of the pandemic is unknown; thus, language educators had no choice but to adapt to the new normal: digital learning. Digital learning is not a new thing; it 
commenced when the internet was globally spread and affordable to middle-class citizens [2]. It provides an environment that gives room for students' development in academic and 21 st-century skills [3]. Digital learning allows them to access and share ideas with other students with an instructor's help or independently.

In times of need, independent learning provides extra help to certain subjects needing improvements or meaningfully spend the stay-at-home time during Covid-19. Independent learning refers to students independently manage their process and strategy of learning. It does not mean that students work on their own without any assistance; instead, they can lead a peer-discussion about a problem and consult an instructor for further assistance. This method can also support students when the conventional learning methods are not possible: during a pandemic, being far from a formal education institution, and lacking the time and money to afford foreign language classes.

Even before the pandemic, digital and independent language learning is accessible through social media, such as Youtube or Facebook. Learning a foreign language has been made easy, even though a teacher-guided course can never be replaced. The Indonesian language has been gaining popularity among international learners. The dissemination of the Indonesian language to develop, foster, and improve it internationally is stated in the XI Indonesian Language Congress in 2018; the Indonesian government shows its earnest effort by issuing Law No.24 of 2009 article 44 concerning a commitment to improving Indonesian to be an international language gradually, systematically and sustainably. On its official website, the Language Development Agency states that around 45 domestic institutions and 36 countries in the world with 130 institutions provide Bahasa Indonesia Untuk Penutur Asing (BIPA) programs Indonesian language learning for foreign speakers [4]. He added that the management of the BIPA program at home and abroad involves universities, foreign cultural centers, the Indonesian Embassy, and course institutions, supporting BIPA learning facilities. The teamwork and international students' interest in studying BIPA indicate that research and development of BIPA teaching-learning are imperative.

The Indonesian government issued a curriculum for BIPA as stipulated in the Regulation of the Minister of Education and Culture No. 27 of 2017. The curriculum is aligned with the CEFR (Common European Framework Reference for Languages) to facilitate BIPA learners' transfer between institutions [5]. There are seven BIPA learning levels: BIPA 1, BIPA 2, BIPA 3, BIPA 4, BIPA 5, BIPA 6, and BIPA 7. BIPA 1 and BIPA 2 are beginner levels focusing on the learners' ability to interact in daily topics. BIPA 3 and BIPA 4 are intermediate levels focusing on the learners' ability to argue, report observations of events, and communicate daily. BIPA 5 and 6 are advanced levels focusing on the learners' ability to express opinions on various topics spontaneously; BIPA 7 is also an advanced level focusing on the learner's ability to express opinions spontaneously and reconstruct arguments and data in presenting their opinions coherently.

The Indonesian language is mostly studied or taught as a foreign language; thus, it is not used daily by international students. BIPA students, especially those abroad, may only receive Indonesian language exposure in class or small groups; so, they have minimal access to the input. According to Krashen, input or language exposure is significant in language learning[6]. Ortega suggested that comprehensible input can help language learners. It can be done by adjusting the words or expressions used to the learner's ability level [7]. Intermediate and advanced learners might find authentic learning media on YouTube streaming, news broadcasts from TV or radio effortless; they already have the skill and vocabulary to communicate or understand complex topics. On the contrary, beginner learners still need learning media with simple vocabulary or expressions, so accessing authentic media may not be helpful for them. Accordingly, this study focuses on developing learning media for the entry-levels (BIPA 1 and 2).

Adranysah asserted that learning media is an essential part of BIPA learning so that the Language Development Agency has prepared and distributed learning media to BIPA teaching institutions, including that of listening skills [4]. From this information, it seems that BIPA learning media are only available in formal and selected institutions; thus, independent learners may not be facilitated, especially those at the entry-levels. On this background, we developed Podcasts of which the contents were created based on the official BIPA curriculum issued by the Ministry of Education and Culture of the Republic of Indonesia. The audio recordings serve as listening learning media for beginner level learners that can be accessed independently. Since downloading audio files from the internet made easy, Podcasts have been an option in language learning. Learners can stay at home and 
choose their time to study; podcasts can facilitate independent learning. However, one should not attempt to replace a language course using Podcasts entirely; instead, they should complement learners to improve their listening skills. They can play and replay the audio at their convenience. Podcasts provide additional practices and enrich their vocabulary.

Previous research indicated that Podcast can potentially increase students' ability by promoting reflective thinking and independent learning [8], leading to successful learning. Podcast mediates students' learning to achieve certain ability of a language; it will allow them to independently regulate their learning and achieve high cognition [9]. Toyib \& Muzakki showed increased student participation in class discussion and increased average test scores after using Podcasts; thus, students responded positively to the use of Podcast. [10][11] Abdous et al., in their research on Mobile Assisted Language Learning (MALL), compared the use of podcasts integrated into the curriculum to podcasts as complementary learning; the results indicated that podcasts had promising potential if used not only as review material.[12] Selwood et al. stated that there was no difference between textbooks and podcasts when used in class; this was based on 1) the length of the study (only four months), 2) each class ran once a week for 90 minutes, and 3) the assessment used a TOEIC test to measure the students' listening skills and vocabulary. The researchers argued that podcasts could be applied in learning as an option besides textbooks. Fatima also supported this finding [13]; she used Podcasts of lectures to supplement the traditional classes. It was not designed to replace the regular lectures, it just helped students study anywhere, anytime, and at their pace.

Luna and Cullen disclosed that $45 \%$ of students in a course at Harvard Extension School found that Podcast more efficient than reviewing notes. They proposed advantages of using a podcast in learning: (a) Flexibility and convenience (b) Keeping up with the content (c) Reducing distance-students isolation (d) Student engagement (e) Improving learning and boosting the learning experiences. Several studies revealed student-generated podcasts used to create a portfolio [15]. Previous research showed that short and moderate podcast episodes, containing educational overview, study guides or curriculum content, were preferable [16]. Previous studies show that podcasts can be used as an optional media besides textbooks, proven to help students' learning process. Therefore, podcast development in BIPA learning is feasible. Developing podcast content for BIPA can help students learn from home due to the pandemic requiring BIPA students not to come to Indonesia.

\subsection{Podcast as learning media}

Podcasts are audio or video content available on the Internet. People can listen and download it to a computer or portable media player on a smartphone. [17] Unlike radio programs that have a specific broadcast time, downloaded Podcasts can repeat recorded episodes of programs at any time. There are many topics to choose from on a Podcast, such as art, business, comedy, horror, drama, education, and games. In learning, this program will be beneficial if used for teaching in class or independent study due to its easy access. The podcast is one of the technologies considered in language learning with all the conveniences and features.

\subsection{Language skill}

Listening skills are essential for learners to master a foreign language. Listening is classified as receptive language skills nearly related to language production. A person can produce language if he has input from the results of receptive language skills. According to Khrasen, the input is the essence of language acquisition; language skills depend on a comprehensible input [18]. Nevertheless, input requires other components to build complete language acquisition. Input will not function unless there is interaction in the language acquisition process [19]. There are three interrelated components in the acquisition of a second language: input, interaction, and production [20].

The listening skill is considered more challenging than other language skills due to several factors, such as psychological factors including distraction, demotivation, feelings of nervousness due to lack of linguistic knowledge such as grammar or lack of strategic ability to overcome all phases of listening difficulties such as perception, description, and understanding speech [21]. Based on his research on the listening skills of French learners, Graham found that listening was a language skill difficult to master [22].

\subsection{Problems in the listening skill}

As previously mentioned, listening skill is considered challenging to master. To explore and find the solution to this problem, researchers and practitioners need to work together and discuss all aspects of listening skills in language learning. Various kinds of problems lead to obstruction of the mastery of listening skills, viz. the recording quality, cultural differences, new vocabulary, duration of reading material, long or short of listening, and 
accents [23]. The speaker's accent is one of the main highlights for learners. $66 \%$ of students considered a speaker's accent as one of the most significant problems [24]. Apart from this, pronunciation is also part of the problem; the pronunciation of words is different from their spelling [25]. Other listening problems include limited vocabulary, poor grammar, and misinterpretations of listening tasks [22]. In learning the listening skill, the materials prepared by the teacher can be a problem when taught without listening strategies [26].

\subsection{Independent study}

Independent learning is a process, method, and educational philosophy accommodating learners to gain knowledge from their efforts [27]. Students who learn independently have the potential to maximize their learning outcomes as they are free to determine their learning goals and ways to achieve them independently [28]. In other words, learners are fully responsible for the process, method, and learning outcomes. They must think critically in solving problems encountered during independent learning. The independence applied in the learning process is considered an essential aspect of popularizing lifelong learning. Learners need the ability to learn independently; aside from formal education, they can continue the learning process [28]. Independent learning activities must be carried out deliberately and continuously throughout the years to improve a learner's competence and quality of life. In formal and informal learning, independent learning skills can be improved through appropriate learning approaches and strategies [29]. Learning media also plays a crucial role in independent learning. Accordingly, the researcher attempted to facilitate BIPA students in implementing the independent learning process through developing Podcasts as listening learning media.

\section{RESEARCH METHOD}

To develop a Podcast to aid the beginning level of BIPA in training their listening skills independently, this study adapted the R\&D cycle coined by Borg \& Gall (1996). The steps included: (1) Need analysis, (2) Product Development, (3) Expert Validation, and (4) Product Revision, (5) Final product prototype. Due to limitation of the time and access to the beginning level learners of Indonesian as a foreign language (BIPA), a decision to omit field try out was made. In short, the R\&D cycles of this study is ilustrated in Figure 1:

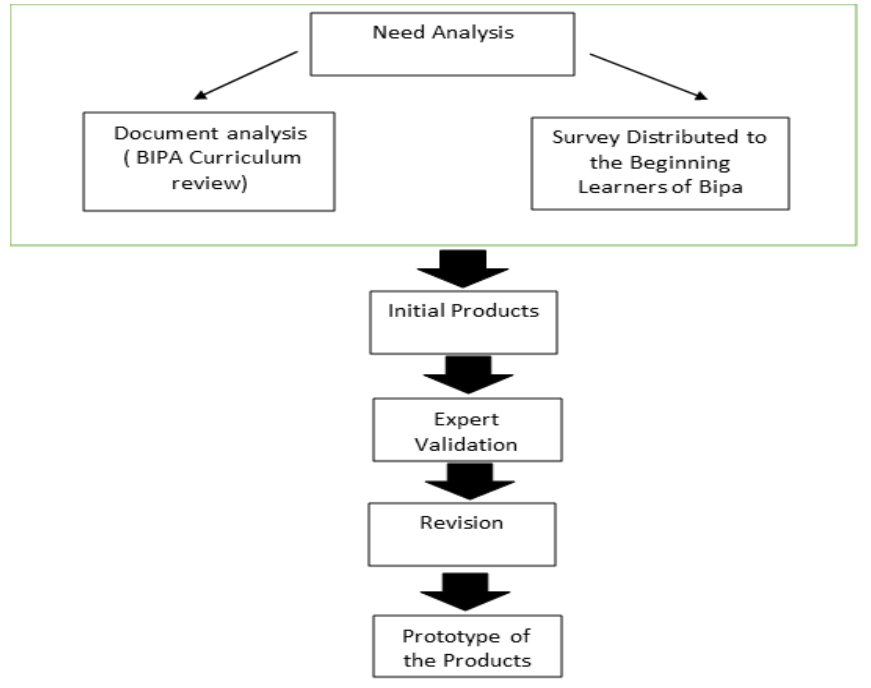

Figure 1. R\&D cycle of this study

The Need Analysis was conducted in two stages. The first stage was analyzing the BIPA curriculum designed by the Indonesian Ministry of Education to find out themes and topics that should be covered in the listening material for the beginning level of Indonesian as a Foreign Language (BIPA) learners. Then, the second stage was distributing a mini survey through google classroom to examine which themes and topics are derived from the curriculum are deemed to be important by the learners. After conducting the Need Analysis, in the second cycle, the preliminary scripts and audio file and sets of comprehension questions were developed according to the chosen topics.

In the third cycle, Expert Validation, three experts were asked to validate the preliminary product. To conduct the validation, we invited three experts who have been working as a BIPA teacher, program designer, and researcher for more than five years. These three experts were chosen as they have experience in developing BIPA materials, dealing with students from various countries and background, and most importantly they have extensive involvement in working with learners in the beginning level. The preliminary products were validated in term of (1) the audio presentation, including the articulation of the speakers, the intonation of the speakers, and the back sound effect used in the audio, the duration of the video, (2) the content of the audio, including the topics, the vocabulary used in the audio, the grammar and sentence structure used in the dialogue, whether or not the speed rate of the speakers is suitable for the beginning learners of BIPA, (3) The quality of the 
listening comprehension questions which accompany each topic. To validate the initial products, the experts were asked to answer a set of open-ended questionnaires. (see Appendix 1 for the complete version of the Expert Validation Questionnaire). In the last cycle, some revision was made according to the expert validation result.

\section{RESULTS}

The BIPA Curriculum designed by the Ministry of Education of Indonesia is originally developed based on the Common European Framework of Reference for Languages (CEFR). The Indonesian curriculum categorized beginner level into two stages, BIPA 1 and BIPA 2. As explained in BIPA 1, learners must be able to use and understand everyday familiar expression and basic phrases to introduce themselves and to fulfil their basic needs in a daily conversation, including introducing their names, address, occupation, family, and others. In BIPA 2, learners should be able to respond or interact in the public facilities which deemed to be closed to the learners' everyday lives, such as conversation at the bank, hospital, immigration office, airport, library, terminal, and others. In both stages, focusing on the listening skill, learners are required to be able to extract the main or important information that they heard. Therefore, we add a set of comprehension questions following each audio files that we developed. The comprehension questions are in the form of multiple choices WH questions. After analyzing the curriculum, we brought up three broad themes, Your Surroundings, Daily Activities, and Important Public Spaces, each theme followed by three topics. Furthermore, we also developed a set of subtopics for each of the topics. The themes and the topics are summarized in Table 1:

TABLE 1. Initial themes and topics during need analysis derived from BIPA curriculum

\begin{tabular}{|c|c|c|}
\hline Theme & Topics & Sub-Topics \\
\hline \multirow[t]{2}{*}{$\begin{array}{c}\text { Your } \\
\text { Surrounding } \\
\mathrm{s}\end{array}$} & Family & $\begin{array}{ll}\text { 1. } & \text { Family Tree } \\
\text { 2. } & \text { Family profile } \\
\text { 3. } & \text { Physical } \\
\text { appearance of } \\
\text { family members }\end{array}$ \\
\hline & School & $\begin{array}{l}\text { 1. Making friends } \\
\text { at school } \\
\text { 2. } \begin{array}{l}\text { Borrowing } \\
\text { books from a }\end{array} \\
\text { library } \\
\text { 3. Having some } \\
\text { meal in a school } \\
\text { cafeteria }\end{array}$ \\
\hline
\end{tabular}

\begin{tabular}{|c|c|c|}
\hline & $\begin{array}{c}\text { Workplac } \\
\mathrm{e}\end{array}$ & $\begin{array}{l}\text { 1. Describing a job } \\
\text { 2. Getting to know } \\
\text { new co-workers } \\
\text { 3. Workplace } \\
\text { location/directio } \\
\text { n }\end{array}$ \\
\hline \multirow[t]{3}{*}{$\begin{array}{c}\text { Daily } \\
\text { Activities }\end{array}$} & Shopping & $\begin{array}{ll}\text { 1. } & \begin{array}{l}\text { Bargaining in } \\
\text { a traditional } \\
\text { market }\end{array} \\
\text { 2. } & \begin{array}{l}\text { Shopping in a } \\
\text { supermarket }\end{array} \\
\text { 3. } & \begin{array}{l}\text { Buying } \\
\text { something in } \\
\text { a small shop }\end{array} \\
\end{array}$ \\
\hline & $\begin{array}{l}\text { Weekend } \\
\text { Activities }\end{array}$ & $\begin{array}{ll}\text { 1. } & \begin{array}{l}\text { Meeting up } \\
\text { with friends }\end{array} \\
\text { 2. } & \begin{array}{l}\text { Going to a } \\
\text { cinema }\end{array} \\
\text { 3. } & \begin{array}{l}\text { Having meal } \\
\text { in a restaurant }\end{array}\end{array}$ \\
\hline & $\begin{array}{l}\text { Doing } \\
\text { Sports }\end{array}$ & 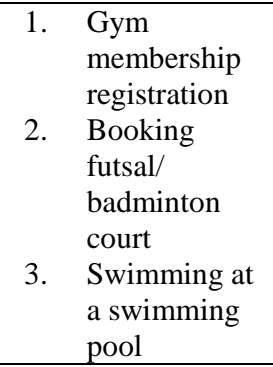 \\
\hline \multirow[t]{2}{*}{$\begin{array}{l}\text { Important } \\
\text { public place }\end{array}$} & Airport & $\begin{array}{l}\text { 1. Random } \\
\text { checking at } \\
\text { the airport } \\
\text { 2. Lost and } \\
\text { found }\end{array}$ \\
\hline & Doctor & $\begin{array}{ll}\text { 1. } & \text { Making } \\
\text { appointments } \\
\text { 2. Health } \\
\text { consultation }\end{array}$ \\
\hline
\end{tabular}

To assure that the topics and sub-topics correspond with the learners' needs, we distributed a survey to fourteen BIPA learners through google form. For the "Your Surroundings" topics, the survey indicates that $40 \%$ or most of the respondents opt to put Family as the most important topics followed by Schools, and Workplace. Therefore, we developed three conversation for the Family topic based on three subtopics: Family Tree, Family Profile, Physical appearance of family members. Then, for the second topic, School, we developed two conversation based on two subtopics, Making Friends at School and Borrowing a Book from the Library. These two sub-topics were chosen because $60 \%$ or most of the respondents have ranked these two sub-topics as the most important sub-topics. For the least preferred topic, Workplace, $50 \%$ of the 
respondents agreed to vote for a sub-theme namely "Describing a Job" to be developed into a full script.

The result of the survey for the second theme, Daily Activities, indicates that $37.5 \%$ or most of the respondents have place Shopping as the most important topic, followed by Weekend Activities as the second most important, and Doing Sport as the least important one. As Shopping deemed to be the most preferred topic, all three sub-topics; Bargaining at the Traditional Market, Shopping at the Supermarket, and Shopping at the Small Shop were all covered in the present listening material. Then, all three subtopics (Meeting Up with Friends, Going to a Cinema, and Having Meal at the restaurant) for the Weekend Activities topic were all developed into three complete scripts for the listening materials due to the percentage of the respondents who opt for each corresponding sub-topic was equally distributed.
Lastly, Doing Sport as the least preferred topic only followed by one sub-topic namely Gym Membership Registration as this sub-topic gained highest amount of vote $(80 \%)$.

The survey for the third themes, Important Public Places, indicates that Airport topic is more preferred than Going to the Doctor topic, 71,4\% and 28.6\% respectively. For that reason, all two sub-topics for the Airport topic, Random Checking at the Airport and Lost and Found, are covered in the listening material under development. On the other hand, Going to the Doctor only followed by one subtopic entitled Heath Consultation since more respondents (70 \%) opted for this sub topics rather than the other subtopic. The Summary for the Need Analysis result to determine Themes, Topics, and Subtopics deemed to be preferred by the learners is depicted in Table 2 :

TABLE 2. Themes, topics, and sub-topics covered in the listening materials

\begin{tabular}{|c|c|c|}
\hline Theme & Topics & Sub-Topics \\
\hline \multirow[t]{3}{*}{$\begin{array}{c}\text { Your } \\
\text { Surroundings }\end{array}$} & Family & $\begin{array}{ll}\text { 1. } & \text { Family Tree } \\
\text { 2. } & \text { Family profile } \\
\text { 3. } & \text { Physical appearance of family } \\
\text { members }\end{array}$ \\
\hline & School & $\begin{array}{ll}\text { 1. } & \text { Making friends at school } \\
\text { 2. } & \text { Borrowing books from a } \\
\text { library }\end{array}$ \\
\hline & Workplace & Describing a job \\
\hline \multirow[t]{3}{*}{ Daily Activities } & Shopping & $\begin{array}{ll}\text { 1. } & \begin{array}{l}\text { Bargaining in a traditional } \\
\text { market }\end{array} \\
\text { 2. } & \text { Shopping in a supermarket } \\
\text { 3. } & \begin{array}{l}\text { Buying something in a small } \\
\text { shop }\end{array}\end{array}$ \\
\hline & Weekend Activities & $\begin{array}{ll}\text { 1. } & \text { Meeting up with friends } \\
\text { 2. } & \text { Going to a cinema } \\
\text { 3. } & \text { Having Meal at the Restaurant }\end{array}$ \\
\hline & Doing Sports & 1. Gym membership registration \\
\hline \multirow[t]{2}{*}{$\begin{array}{c}\text { Important public } \\
\text { place }\end{array}$} & Airport & $\begin{array}{l}\text { 1. Random checking at the } \\
\text { airport } \\
\text { 2. Lost and found }\end{array}$ \\
\hline & Doctor & 1. Health consultation \\
\hline
\end{tabular}

This prototype will be developed as a podcast, which will be distributed through the Google Podcast platform. The podcast has audio and practice questions. In the development process, this media is validated by the Indonesian Language for
Foreign Speakers (BIPA) experts to determine the suitability of topics and materials specifically designed for beginner-level learners. The BIPA expert's assessment can be seen in Table 3: 
TABLE 3. The expert validation results of the podcast quality

\begin{tabular}{|l|l|l|l|}
\hline No & \multicolumn{1}{|c|}{ Aspect } & \multicolumn{1}{c|}{$\%$} \\
\cline { 3 - 4 } & & \multicolumn{1}{|c|}{$\begin{array}{c}\text { Strongly } \\
\text { Agree }\end{array}$} & \multicolumn{1}{c|}{ Agree } \\
\hline 1. & Podcast sound can be heard well & $100 \%$ & \\
\hline 2. & The speaker is into his/her role & $33 \%$ & $67 \%$ \\
\hline 3. & $\begin{array}{l}\text { Sound effects as a podcast context-enhancer are well presented and do not interfere } \\
\text { with the podcast content }\end{array}$ & $33 \%$ & $67 \%$ \\
\hline 4. & The speaker's articulation is clear & $100 \%$ & \\
\hline 5. & The pauses and intonation of the utterances are in line with the context & $33 \%$ & $67 \%$ \\
\hline 6. & The podcast duration is appropriate & $100 \%$ & \\
\hline
\end{tabular}

Based on Table 3, there were six things assessed. First, Podcast sound quality: $100 \%$ strongly agreed that the Podcast sound could be heard well. Second, the speaker being into his/her role: 33\% strongly agreed, and $67 \%$ agreed. Third, the sound effects used in the Podcast: $33 \%$ strongly agreed, and $67 \%$ agreed that the sound effects on the Podcast were well presented and did not interfere with the content.
Fourth, the speaker's articulation: 100\% strongly agreed that the speaker's articulation could be heard clearly. Fifth, pause and intonation: 33\% strongly agreed, and $67 \%$ agreed that the pauses and intonation of the utterances were in line with the context. Sixth, Podcast duration: $100 \%$ strongly agreed that the Podcast duration was appropriate.

TABLE 4. The expert validation results on the suitability of podcast content with BIPA curriculum

\begin{tabular}{|c|c|c|c|}
\hline \multirow[t]{2}{*}{ No } & \multirow[t]{2}{*}{ Aspect } & \multicolumn{2}{|c|}{$\%$} \\
\hline & & $\begin{array}{c}\text { Strongly } \\
\text { Agree }\end{array}$ & Agree \\
\hline 1. & $\begin{array}{l}\text { Podcast topics correspond to the beginner-level (BIPA 1) in the BIPA curriculum } \\
\text { issued by the Minister of Education and Culture }\end{array}$ & $67 \%$ & $33 \%$ \\
\hline 2. & $\begin{array}{l}\text { Podcast content (vocabulary and grammar) correspond to the beginner-level listening } \\
\text { skill indicator (BIPA 1) in the BIPA curriculum issued by the Minister of Education } \\
\text { and Culture }\end{array}$ & $33 \%$ & $67 \%$ \\
\hline 3. & The speaker's speech rate is appropriate for the beginner-level learners & $67 \%$ & $33 \%$ \\
\hline
\end{tabular}

As seen in Table 4, there were three aspects assessed. First, the Podcast topic: $67 \%$ strongly agreed that the Podcast topic corresponded to the beginner-level in the BIPA curriculum issued by the Minister of Education and Culture. Second, Podcast content: $33 \%$ strongly agreed, and $67 \%$ agreed that the content, including vocabulary and grammar, was in accordance with indicators of listening skills for beginner-level students in the BIPA curriculum issued by the Minister of Education and Culture. Third, the speaker's speech rate: 67\% strongly agreed, $33 \%$ agreed that the speaker's speech rate was appropriate for beginner-level BIPA learners.

TABLE 5. The expert validation of the practice-questions' quality

\begin{tabular}{|l|l|l|l|}
\hline No & \multicolumn{1}{|c|}{ Aspect } & \multicolumn{2}{|c|}{$\%$} \\
\cline { 3 - 4 } & & $\begin{array}{c}\text { Strongly } \\
\text { Agree }\end{array}$ & \multicolumn{1}{c|}{ Agree } \\
\hline 1. & The instructions are clear and easy to understand & $67 \%$ & $33 \%$ \\
\hline 2. & The questions' sentence-arrangement is easy to understand & $100 \%$ & \\
\hline 3. & The answer choices are correct & $67 \%$ & $33 \%$ \\
\hline
\end{tabular}

Based on Table 5, three aspects were assessed. First, question instructions: $67 \%$ strongly agreed, and $33 \%$ agreed that the practice instructions were clear and easy to understand. Second, the questions' sentence-arrangement: $100 \%$ strongly agreed that the questions are easy to understand. Third, the choice of answers: 67\% strongly agreed, 33\% agreed that the answers to practice questions are correct.

There were three Indonesian Language experts for Foreign Speakers (BIPA) providing comments and suggestions for Podcast revisions. Some commented on the low quality of the Podcast, although the speakers were into the roles; some said 
that several back sounds were unclear, and some practice questions were inaccurately written. Nonetheless, the Podcast was developed well as the indicators were met, back sounds supported the dialogue's context. Some dialogues were considered too long; some speech rates were too fast. The researchers also need to pay attention to using the interjection "here, here, please".

The BIPA expert suggested incorporating Indonesian culture in the dialogue. The speakers should try omitting the accent that shows regionalism, and the number of practice questions and answer choices should be consistent. They also suggested revising the Podcast prototype. This prototype serves as the basis for Podcast development, which will later be distributed into a platform accessible by beginner learners.

\section{DISCUSSION}

In developing this podcast prototype, the experts highlighted three aspects: the speaker's speech rate, the sound effects, and the use of interjection.

The speaker's speech rate has been a debatable topic. In developing this Podcast prototype, the researchers designed the conversations using a natural speech rate as native speakers. According to the Common European Framework of Reference (CEFR), which is the primary reference in the development of the BIPA Curriculum, beginner level learners "can interact in a simple way provided the other person talks slowly and clearly and is prepared to help". Second language learners have higher scores when they listen to a conversation with a slow rate [30]. It is different from the research conducted by Hayations study showed that second language learners showed increased understanding when listening to conversations with a natural speed instead of a slow one. Accordingly, the researchers recorded the audio at a natural speed. Podcasts that provide a natural speech rate can train BIPA students to face real situations in Indonesia because native speakers will not slow down their speech when communicating.

The sound effect/background noise is used to create a real atmosphere during the conversation, for example, in malls, supermarkets, markets, airports, hospitals, and others. However, some argue that background noise in listening material can interfere with second language learners' learning process. Some studies revealed that learners find it more difficult to recognize words 'interrupted' with background noise in the foreign language being studied than in their native language, even for the proficient ones. One of them is research conducted by Fujita [30]. D who examined the effects of speech rate and background noise on EFL learners. His research results stated that the learners had higher scores with the slow speech than the fast speech, and the scores for speech without background sounds were higher than with background sounds. The students' listening comprehension score was the lowest when the speech had background noise and a fast rate. Scharenborg \& Os conducted a study on the effect of background noise on word recognition for non-native learners. The results of his research showed that although spoken-word recognition in the presence of background noise is harder in a nonnative language than in one's native language, this difference is not due to a differential effect of background noise on native and non-native listening. Instead, it can be explained by differences in language exposure, affecting the uptake and use of phonetic and contextual information in the speech signal for spoken-word recognition [32]. These results add to the explanations and new theories of Fujita's research. So, the problem is not just background noise; it can be conditioned in such a way so as not to interfere with the clarity of pronunciation and every word in the podcast content.

Yang, Jiang, \& Zhao conducted a similar study on background noise in learning English listening in China. The results showed that the effects of different noise types on English listening comprehension among Chinese college students varied depending on their learning styles. Specifically, assimilative and differential learning style preferences were more beneficial for English listening comprehension in noise than convergent and accommodative learning styles [33]. This discussion shows that background noise initially can interfere with the listening learning process for second language learners. However, other research deeply examined this problem, resulting that background noise is not the leading cause. The problem is learning to listen, which lies in language exposure differences, affecting the uptake and use of phonetic and contextual information in the speech signal for spoken-word recognition. In addition, the learning styles of BIPA students affect their understanding when listening to materials. Therefore, background noise can be used with slight adjustments to not interfere with the content.

One of the validators underline the used of some interjection, such as sih and nih in the audio. Interjections in Indonesian are complicated to understand as those particles do not really have exact meaning on their own. Since those interjection must be attached to a complete sentence to produce 
meaning, and therefore it is not unsurprising if the validator questioned the occurrence of interjection in the listening materials for beginning students. In our opinion, however, it is essential to introduce interjection to beginning students of BIPA as it is largely used in everyday communication. As explained by Mutiara it is necessary to study interjection in dialogue to better understand the meaning [34]. Considering that interjection hold important role in Indonesian daily communication, even though these particles are challenging to learn, we decided not to remove the interjection from our dialogue. Instead, to allow effective learning to happen, we add short explanation about interjection particles that are used in the audio file before the dialogue start, and therefore the learners have developed background knowledge about that interjection before listening to the dialogue.

\section{CONCLUSION}

Referring to the result and discussion, the following points are concluded in this study:

1. Podcast can help BIPA learners in improving their listening skill independently; students can access and download the recordings to learn at their most convenient time and place.

2. Developing podcasts is beneficial as it can serve as a supplementary media is essential for BIPA learning. Podcasts should not replace a complete course as students still need a teacher's guidance.

3. Natural speech-rate is an option to make learners being used to natural way of communicating; not all listening learning media must be made slower than the natural speech rate.

4. Background sound/noise can help build the atmosphere as podcast only relies on sounds without any visual illustration. It must not, however, be louder than the actual speech of the dialogue to prevent the noise from interfering with the speech clarity.

5. Introducing interjections is essential for beginner learners to help them understand how daily communication in Indonesian works.

\section{ACKNOWLEDGMENTS}

This work is supported by Research and Technology Transfer Office, Bina Nusantara University as a part of Penelitian Terapan Binus entitled 'Pengembangan
Konten Podcast Sebagai Media Pembelajaran Menyimak Mandiri Bagi Pemelajar Bipa 1' with contract number: No: 025/VR.RTT/IV/2020 and contract date: 6 April 2020.

\section{REFERENCES}

[1] E. Spodark, "French in Cyberspace: An Online French Course for Undergraduates," CALICO J., vol. 22, pp. 83-101, Jan. 2004, doi: 10.1558/cj.v22i1.83-101.

[2] S. Hubackova, "History and Perspectives of Elearning," Procedia - Soc. Behav. Sci., vol. 191, pp. 1187-1190, 2015, doi: 10.1016/j.sbspro.2015.04.594.

[3] V. Z. Mashhadi and M. R. Kargozari, "Influences of digital classrooms on education," Procedia Comput. Sci., vol. 3, pp. 1178-1183, 2011, doi: 10.1016/j.procs.2010.12.190.

[4] Adryansah, "Profil BIPA Badan Pengembangan dan Pembinaan Bahasa," Badan Pengembangan dan Pembinaan Bahasa, 2012. http://badanbahasa.kemdikbud.go.id/laman bahasa/info_bipa.

[5] L. Muliastuti, Bahasa Indonesia bagi Penutur Asing acuan teori dan pendekatan. Jakarta: Yayasan Pustaka Obor Indonesia, 2017.

[6] S. D. Krashen, The Input Hypothesis: Issues and Implications. New York: Longman, 1985.

[7] L. Ortega, Understanding second language acquisition. London: Taylor \& Francis Ltd., 2014.

[8] H. K. J. Liu, "Correlation research on the application of e-learning to students' selfregulated learning ability, motivational beliefs, and academic performance," Eurasia J. Math. Sci. Technol. Educ., vol. 12, no. 4, pp. 1091-1100, 2016, doi: 10.12973/eurasia.2016.1559a.

[9] E. Bagarukayo, P. Ssentamu, T. Mayisela, and C. Brown, "Activity Theory as a lens to understand how Facebook develops knowledge application skills," Int. J. Educ. Dev. Using Inf. Commun. Technol., vol. 12, no. 3, pp. 128-140, 2016.

[10] M. Toyib, S. Humaisyi, and M. H. Muzakki, "Penggunaan Podcast Dalam (Stad) Untuk Meningkatkan Kemampuan Menyimak Pada Mata Kuliah Listening I Prodi Tadris Inggris Jurusan Tarbiyah Stain Ponorogo," Kodifikasia, vol. 6, no. 1, 2013, doi: 
10.21154/kodifikasia.v6i1.204.

[11] M. Abdous, M. M. Camarena, and B. R. Facer, "MALL technology: Use of Academic podcasting in the foreign language classroom," $\operatorname{Re} C A L L$, vol. 21, no. 1, pp. 76-95, 2009, doi: 10.1017/S0958344009000020.

[12] J. Selwood, J. Lauer, and K. Enokida, "What are more effective in English classrooms: textbooks or podcasts?," CALL communities Cult. - short Pap. from EUROCALL 2016, vol. 2016, pp. 424-428, 2016, doi: 10.14705/rpnet.2016.eurocall2016.600.

[13] F. Mncube-barnes, D. Ed, P. Walker, R. Block, and A. Whitehead, "Podcasting in Medical Education: A Literature Review Fatima Mncube-Barnes, Ed.D, MPH, MSIS; Philip Walker, MLIS; Robert Block, DDS, MS, FACDS; and Amelia Whitehead, MLS."

[14] G. Luna and D. Cullen, "Podcasting as Complement to Graduate Teaching : Does it Accommodate Adult Learning Theories?," Int. J. Teach. Learn. High. Educ., vol. 23, no. 1, pp. 40-47, 2011.

[15] D. Forbes and E. Khoo, "Voice over distance: a case of podcasting for learning in online teacher education," Distance Educ., vol. 36, no. 3, pp. 335-350, 2015, doi: 10.1080/01587919.2015.1084074.

[16] C. Almeida-Aguiar and A. A. Carvalho, "Exploring podcasting in heredity and evolution teaching," Biochem. Mol. Biol. Educ., vol. 44, no. 5, pp. 429-432, 2016, doi: 10.1002/bmb. 20965.

[17] D. Geoghegan, Michael, Klass, Podcast Solutions: The Complete Guide to Audio and Video Podcasting. New York City: Apress, 2007.

[18] S. D. Krashen, "The Monitor Model for Adult Second Language Performance," in Readings on English as a Second Language, K. Croft, Ed. Cambridge: Winthrop Publishers, Inc., 1980.

[19] A. M. Schwartz, "Listening in a foreign language.," p. 46, 1998, [Online]. Available: http://eric.ed.gov/?id=ED433723.

[20] S. Zhang, "The Role of Input, Interaction and Output in the Development of Oral Fluency," English Lang. Teach., vol. 2, no. 4, pp. 91-100, 2009, doi: 10.5539/elt.v2n4p91.

[21] İ. Kök, "Relationship between Listening Comprehension Strategy Use and Listening
Comprehension Proficiency," Int. J. List., vol. 32, no. 3, pp. 163-179, 2018, doi: 10.1080/10904018.2016.1276457.

[22] S. Graham, "Listening comprehension: The learners' perspective," System, vol. 34, no. 2 , pp. 165-182, 2006, doi: 10.1016/j.system.2005.11.001.

[23] M. Bingol, B. Celik, N. Yildiz, and C. Mart, "LISTENING COMPREHENSION DIFFICULTIES ENCOUNTERED BY STUDENTS IN SECOND LANGUAGE LEARNING CLASS," pp. 2146-7463, Nov. 2014

[24] C. Goh, "A cognitive perspective on language learners' listening comprehension problems," System, vol. 28, pp. 55-75, Mar. 2000, doi: 10.1016/S0346-251X(99)000603 .

[25] A. Bloomfield, S. C. Wayland, E. Rhoades, A. Blodgett, J. Linck, and S. Ross, "What makes listening difficult?," Univ. Maryl., no. April, p. 92, 2010, [Online]. Available: http://www.dtic.mil/dtic/tr/fulltext/u2/a550 176.pdf.

[26] G. Seferoglu and S. Uzakgören, "Equipping Learners with Listening Strategies in English Language Classes.," Hacettepe Univ. Egit. Fak. Dergisi-hacettepe Univ. J. Educ., vol. 27, pp. 223-231, 2004.

[27] F. Hermens, "Self-direction for lifelong learning: a comprehensive guide to theory and practice," in Review of Social Economy, vol. 40, no. 1, 1982, pp. 72-74.

[28] S. Sakai, a Takagi, and M. Chu, "Promoting Learner Autonomy: Student Perceptions of Responsibilities in a Language Classroom in East Asia.," Educ. Perspect., vol. 43, no. 1, pp. 12-27, 2010, [Online]. Available: http://files.eric.ed.gov/fulltext/EJ912111.pd f.

[29] B. Zimmerman, "Investigating SelfRegulation and Motivation: Historical Background, Methodological Developments, and Future Prospects," Am. Educ. Res. J. - AMER EDUC RES J, vol. 45, pp. 166-183, Mar. 2008, doi: 10.3102/0002831207312909.

[30] R. Fujita, "The Journal of Asia TEFL Effects of Speech Rate and Background Noise on EFL Learners '," vol. 14, no. 4, pp. 638-653, 2017.

[31] A. Hayati, "The Effect of Speech Rate on Listening Comprehension of EFL learners," Creat. Educ., vol. 01, Jan. 2010, doi: 
10.4236/ce.2010.12016.

[32] O. Scharenborg and M. van Os, "Why listening in background noise is harder in a non-native language than in a native language: A review," Speech Commun., vol. 108, pp. 53-64, 2019, doi: 10.1016/j.specom.2019.03.001.

[33] X. Yang, M. Jiang, and Y. Zhao, "Effects of noise on english listening comprehension among chinese college students with different learning styles," Front. Psychol., vol. 8, no. OCT, pp. 1-12, 2017, doi: 10.3389/fpsyg.2017.01764.

[34] R. Mutiara, "Co-occurences of kok and other markers in colloquial Jakartan Indonesian," J. Pragmat. Res., vol. 1, no. 1, pp. 43-61, 2019, doi: 10.18326/jopr.v1i1.43-61. 